\title{
ARTIFITIAL AGING TIME EFFECT ON CORROSION RESISTANCE FOR FRICTION STIR WELDED AA6061 T6
}

\author{
Huda Mohammed Abdul-Aziz ${ }^{1}$, Nasser Malik Abbas ${ }^{2}$, Amjad Hussain Jasim \\ ${ }^{1,2}$ Institute of Technology Baghdad, ${ }^{3}$ University of Technology \\ Email: kif1962@yahoo.com ${ }^{1}$, nasserma1@yahoo.com², Amjadbaghdad362yahoo.com ${ }^{3}$ \\ (Received: 23/5/2012; Accepted: 11/10/2012)
}

\begin{abstract}
This work aims to study the effect of heat treatment on the corrosion resistance of friction stir welded joint of AA 6061 T6.

Friction stir welding process carried out using CNC milling machine with a tool of rotational speed $(1000 \mathrm{rpm})$ and welding speed of $(20 \mathrm{~mm} / \mathrm{min})$ to obtain butt joint welding of sheets which prepared from AA $6061 \mathrm{~T} 6$ in the dimensions of (100 mm x 70mm x 6mm ).

After obtaining the welded joints many corrosion specimens were prepared in dimensions of $\left(15^{*} 15^{*} 2\right) \mathrm{mm}$ according to ASTM G 71-31, specimens subjected to solution heat treatment at $500^{\circ} \mathrm{C}$ for half an hour then water quenched, this process followed by artificial ageing at $190^{\circ} \mathrm{C}$ for 2,4 , and $6 \mathrm{hrs}$.
\end{abstract}

All specimens subjected to hardness test and microstructure examination to show the effect of the heat treatment on the mechanical properties and microstructure.

Corrosion behavior of the specimens were studied before and after heat treatment by using potentiostatic method in sea water at $3.5 \% \mathrm{NaCl}$ and temperature of $30^{\circ} \mathrm{C}$, then corrosion rate was calculated by using Tafel equation.

The obtained results show that artificial aging treatment contributed in increasing the corrosion resistance of weld because of presence of precipitate phases occurring in the microstructures of the welding zone but corrosion resistance decreased as increasing ageing time because of the increasing of the precipitating elements. It was found that artificial ageing for 2 hours gives the best corrosion resistance.

Keywords:- Friction stir welding, 6061T6 Al-alloys, corrosion resistance, solution heat treatment. 


\section{INTRODUCTION}

In recent years, aluminum alloys have attracted attention of many researchers, engineers and designers as promising structural materials for automotive industry or aerospace applications. Especially, Aluminum-magnesium-silicon ( $\mathrm{Al}-\mathrm{Mg}-\mathrm{Si}$ ) denoted as 6xxx series aluminum alloys have been studied extensively because of their benefits such as medium strength, formability, weld ability, corrosion resistance, and low cost, comparing to other aluminum alloys ${ }^{(1)}$. Age hardening heat treatment (T4 or T6) is generally used for increasing the strength in heat treatable aluminum alloys of $(2000,6000 \text { and } 7000 \text { series })^{(2)}$.

In products of fusion welding processes such as (TIG) or (MIG), hot cracking often occurs without filler metals. These problems can be eliminated by Friction stir welding (FSW) process. Friction Stir Welding (FSW) has emerged as a new solid state joining technique ${ }^{(3)}$, especially for aluminum alloys. It was invented by The Welding Institute (TWI) in 1991.

In friction stir welding, a tool with a probe attached to its tip is rotated while being pushed against the butt sections of the pieces of metal to be welded. The frictional heat generated by this process softens the metal to produce a plastic flow that effectively stirs the metal from the sections on both sides and melding them together to create a weld

The quality and property of the welds are controlled by the welding parameters for the technique, such as pin rotation speed, diameters of the pin and shoulder, pressure and rate of translation of the pin. Fig. (1) ${ }^{(4)}$.

A post weld solution treatment and subsequent ageing result an improvement in mechanical properties (hardness and tensile strength) of Friction Stir Welds of AA6061 and AA2024 aluminum alloys ${ }^{(5),(6)}$ and hardness was found to be uniform across the weld region after the PWHT while the brittleness of the welds did not reduced when the heat treatment reduce the grain size ${ }^{(7)}$.

Won Bae Lee (8) investigate the effect of PWHT (post weld heat treated) $6061 \mathrm{~T} 6 \mathrm{Al}$ alloy on hardness distribution and its relating to the precipitates behavior as friction stir welded applied to the alloy, they show that Frictional heat and plastic flow during friction stir welding created a fine, eqiuaxed and elongated microstructure near the weld zone due to dynamic recovery and recrystallization. PWHT (SHT+ Aging) homogeneously recovered the hardness distribution over that of the base metal without softening region, resulted from nonhomogeneously distributed hardness only aging treated. 
Microstructure is directly affected by the microchemistry and the welding parameters such as rotation speed, titling angle tool geometry, etc., which in turn have an effect on the thermal transient and control the mode and the extent of the corrosion behavior of friction stir welds.

Since microstructure and microchemistry are greatly affected by the length of the friction stir welding process, in order to achieve a significant improvement of corrosion resistance of welds it is important to homogenize the microstructure for that a post weld heat treatment and change in microchemistry during welding are ways to improve the corrosion resistance ${ }^{(9)}$.

V. Fahimpour ${ }^{(10)}$ study the corrosion behavior of Al 6061 T6 joined by friction stir welding and arc welding, they found that resistance to corrosion was greater for the FSW grains than the GTAW structure. In both cases, susceptibility to corrosion attack was greater in the welded region than the base metal section. T6 heat treatment resulted in shifting of the corrosion potential towards bigger positive values. This effect was stronger in the welded regions than the base metal section.

Kh. S. Hassan ${ }^{(11)}$ study the effect of heat treatment on corrosion resistance of friction stir welded joint of 2024 T3 Aluminum alloy, they found that Post weld aging treatment leads to increase the corrosion resistance of weld because of precipitation homogeneity occurring in the microstructures of various welding regions.

Aim of this present work is to study the effect of artificial aging time at 2,4,6 hrs on the microstructures and corrosion rate of 6061 T6 aluminum alloy welded by friction stir process choosing the best time that gives the best corrosion resistance.

\section{EXPERIMENTAL WORK}

1- Metal Selected:

The base metal used in this work was 6mm thick AL6061-T6 Aluminum alloy plate, whose chemical composition is provided in Tab.(1) ARL Spectrometer in the specialized institution of engineering industries of Industry ministry, has been used for this purpose.

2- Welding Process:

As shown in Fig. (2), the two sheet metals of $(100 \mathrm{~mm} \times 70 \mathrm{~mm} \times 6 \mathrm{~mm})$ were longitudinally butt welded using CNC milling machine (type Bridgeport). All similar welds of 6061-T6 aluminum alloy were performed using a welding tool made of tool 
steel (T2). The welding tool is composed of shoulder of (20mm diameter) and probe of (5mm diameter and $4.7 \mathrm{~mm}$ length). The welding tool is rotated at high speed and plunged into the joint line between two plates to be butt welded together. In this study, the welding parameters such as tool rotation speed of (1000 rpm) and travel or welding speed of $(20 \mathrm{~mm} / \mathrm{min})$ are constants.

3- Preparation of specimens:

Corrosion Specimens were manufactured by cutting a cross section from the FSW joints with the dimensions of $\left(1.5^{*} 1.5^{*} 0.2\right) \mathrm{cm}$ according to ASTM G 71-30.

4- Categorization of specimens:

Specimens were categorized to simplify the work as in Tab. (2)

5- Heat Treatment:

Included solution heat treatment and aging for aluminum alloy AA 6061-T6 welded joints in electric furnace at temperature of $500^{\circ} \mathrm{C}$ for $30 \mathrm{~min}$ then rapid quenching in water, Following by aging process by pre heating at $190^{\circ} \mathrm{C}$ for $2,4,6 \mathrm{hrs}$ then cooled in air according to Al heat treatment (T6 )

6- Micro hardness test:

The Vickers hardness instrument with a 300gf load was used for hardness profile across the friction stir weld joint.

7- Microstructure examinations:

Specimens in Tab. (2) were prepared for microstructure test including wet grinding operation using emery paper of $\mathrm{SiC}$ with different grits of $(220,320,500$, and 1000). Polishing process was done by using diamond paste of size $(1 \mu \mathrm{m})$ with special polishing cloth. They were cleaned with water and alcohol and dried with hot air. Etching process was done to the samples by using etching solution which is composed of $(99 \% \mathrm{H} 2 \mathrm{O}+1 \% \mathrm{HF})$. Then the samples were washed with water and alcohol and then dried a hair dryer. The friction stir welded joint samples were examined by Nikon ME-600 computerized optical microscope provided with a NIKON camera, DXM-1200F.

8- Corrosion Tests:

Polarization resistance tests were used to obtain the corrosion rates. Cell current readings were taken during a short, slow sweep of the potential. The sweep was taken from $(-100$ to +100$) \mathrm{mV}$ relative to $(\mathrm{OCP})$. Scan rate defines the speed of the potential sweep in $\mathrm{mV} / \mathrm{sec}$. In this range the current density versus voltage curve 
is almost nearly linear. A linear data fitting of the standard model gives an estimate of the polarization resistance, which is used to calculate the corrosion current density (Icorr) and corrosion rate. The tests were performed by using a WENKING Mlab multi channels potentiostat and SCI-Mlab corrosion measuring system from Bank Electroniks-Intelligent control GmbH, Germany 2007, as shown in Fig (3). In this test, aluminum alloy (6061-T6) and FSW samples were used as working electrode (WE), a saturated calomel electrode immersed in the salt solution was used as reference electrode (RE), and a platinum electrode was used as auxiliary electrode (AE).

\section{RESULTS AND DISCUSSION}

\section{1- Micro structure Examinations}

The microstructure of FSW joints can be separated to four zones; base material; heat affected zone (HAZ); thermo-mechanical affected zone (TMAZ) which is affected by heat and deformation but is not re-crystallized containing highly deformed grains from the stirring action and the weld nugget which is a is fully recrystallized region at the weld center. Fig. (4) shows a comparison between the base metal and nugget region indicating the recrystallized grains, where we can see a fine, equiaxed grains due to heavy plastic deformation followed by dynamic recrystallization due to thermo-mechanical processing, this is goes with what ${ }^{(10)}$ achieved.

Fig. (5) shows the microstructures of the of welded joint weld zone (W.Z) for all specimens. The microstructure of Sample (A) shows recrystallized grains with clear grain boundaries. While microstructure of Sample (B) shows a thick grain boundary precipitation and homogeneity in this perception, this thickness is increased as increasing in ageing time where this is obvious in Sample (C) then Sample (D). The thickness in the grain boundaries means that there is a wide precipitate zone.

After heat treatment the grains of the heat treated joints are coarsened because of heating and low cooling. The instability of the grains in the weld zone is largely due to the imbalance between thermodynamic driving forces for the grain growth and the pining forces impeding grain boundary migration ${ }^{(12)}$. The pinning force decreases during solution heat treatment because of the dissolution of precipitate during treatment. As pinning forces decrease, the balance mentioned above breaks down and the grains coarsened. 
It also can be observed from Fig. (5) that variation in grain size of the alloy (6061-T6) depend mainly on the proportion of the silicon and magnesium elements in the alloy and the presence of the other alloying elements causing the forming of different soluble or insoluble compounds in solid state. These results give good evidence that the aging time have an important effect on both microstructure of alloy and their electrochemical properties.

Hardness Profiles.

Fig. (6) indicates the cross-sectional hardness profile from retrieving side metal through center of the weld to advancing metal at a constant rotation speed and welding speed for as-weld and post weld solution treated and aged condition at $500^{\circ} \mathrm{C}$ for 2,4 and $6 \mathrm{hrs}$.

The stir zone shows a great change in the hardness distribution from the weld center, nugget, TMAZ to HAZ and base metal.

Hardness of the stir zone was lower than base metal. The average hardness values in the TMAZ are slightly lower than in the weld nugget while the HAZ region gives the lowest value of hardness, this is because HAZ zone affected only by conducting heat and slow cooling which could cause a coarsening and /or a dissolution of precipitates elements, while the nugget and TMAZ affected by direct heat introducing melting the metal in this area and then rapid cooling which increased the hardness there.

The post welds solution treatment resulted in significant improvement in hardness throughout the weld zone, this is due to the re-precipitation of the precipitates during age treatment, that is increased as the ageing time increased from 2 to 4 then to 6 hours which gives the higher hardness value, and this is goes with what ${ }^{(13)}$ achieved.

\section{2- Corrosion Results}

Aluminum has excellent corrosion resistance in a wide range of water where as in sea water and due to the presence of chloride ions the corrosion rate could be very high ${ }^{(14)}$.Further the corrosion behavior of Al-alloys largely depends on heterogeneity of their microstructures. The friction stir welding process induces dramatic changes in microstructures.

In this study, electrochemical corrosion test by Tafel extrapolation method was carried out on all samples of base alloy of 6061-T6 and FSW in sodium chloride solution of $3.5 \% \mathrm{NaCl}$ to determine corrosion Parameters, such as corrosion potential (Ecorr) and corrosion current (Icorr) as shown in Tab. (3). These parameters will leads to calculate the corrosion rate according to the equation below ${ }^{(15)}$.

C.R (mpy) $=0.13 *$ Icorr $*$ eq.wt $/ \mathrm{d}$ 
Where

mpy $=$ milli-inches per year

Icorr $=$ corrosion current density $(\mu \mathrm{Acm} 2)$

E.W = equivalent weight of the corroding species,

$\mathrm{d}=$ density of the corroding species, $(\mathrm{g} / \mathrm{cm} 3)$.

Fig. (7) shows the polarization curves of the FSW sample of 6061-T6 before and after age hardening heat treatment respectively in $3.5 \% \mathrm{NaCl}$ at temperature of $30^{\circ} \mathrm{C}$. It was shown in Fig. (7a) that the friction stir weld has higher corrosion current (or less corrosion resistance) before age treatment; that is because of microstructure inhomogeneity of weld zones

At heat treatment condition as shown in Fig. (7b) it was noticed that corrosion current (Icorr) is low in sample (B) due to the homogeneity in phases precipitation in microstructures of various welding zones This cause an increasing in hardness ( brittleness) of the metal then the corrosion resistance, and also during FSW process only coarser precipitates could nucleate and grow but not finer ones. This aids in the formation of passive film, which remains more intact on surface of the sample and improves the corrosion resistance of the weld. These results are in agreement with those of other researchers where ${ }^{(9)}$ indicates that heat treatment resulted in improving corrosion resistance by reducing corrosion potential values.

Fig.7 (C, d) shows the polarization curves of Sample (C) and (D) where the ageing time increased to 4 and 6 hours respectively, the corrosion rate increased as increasing the ageing time, this is due to the increasing of the precipitation elements (silicon and magnesium) where these elements locate below $\mathrm{Al}$ in the electrochemical series for that it has a bigger potential than $\mathrm{Al}$ encouraging to core faster than $\mathrm{Al}$.

\section{CONCLUSION}

1- Age hardening heat treatment increases the hardness values of welded joint because of a perception zone and homogeneity or uniform distribution of precipitates in aluminum matrix of friction stir weld zones.

2- Post-weld solution and aging treatment (age hardening) increase the corrosion resistance of the friction stir welded joint because of presence of precipitate phases occurring in the microstructures of the welding zone, and ageing at $2 \mathrm{hrs}$ gives the best corrosion resistance. 
3- Increasing the age hardening time (4 and 6 hours) leads to increase corrosion rate because of the increasing of the precipitating elements.

\section{REFERENCES}

1- Heinz, A., et al., 2000. "Recent development in aluminum alloys for aerospace applications" Materials Science and Engineering, 280(1): pp. 102-107.

2- Ozturk F., Sisman A., Toros S., Kilic S., and Picu R.C., 2010 "Influence of aging treatment on mechanical properties of 6061 aluminum alloy", Materials and Design Vol. 31, pp.972-975.

3- Thomas W.M., Nicholas E. D., Needham J. C. ,Murch M. G. ,Templesmith P. and Dawes C. J., GB 1995, Patent Application No. 9125978.8, Dec. 1991, US Patent No.5460317.

4- Maria Posada, Nguyen P. J., Forrest R. D., Branch J. J. And Denale R., 2003 "Friction Stir Welding Advances Joining Technology", Special Issue AMPIAG, Quarterly Vol. 7, No.3, pp.13-20.

5- Elangovan K., Balasubramanian K., 2008" Influences of post-weld heat treatment on tensile properties of friction stir-welded AA6061 aluminum alloy joints", Materials Characterization journal Volume: 59, Issue: 9, pp. 1168-1177.

6- Krishnaa P.M., Ramanaiah N., 2011 "Effect of Post-Weld Heat Treatment on the Mechanical Properties of Friction Stir Welds of Dissimilar Aluminum Alloys" International Journal of Engineering Science and Technology (IJEST) ISSN: 09755462 Vol. 3 No. 7.

7- Krishnan K. N., 2002 "The effect of post weld heat treatment on the properties of 6061 friction stir welded joints". Journal of Materials Science 37 pp.473-480.

8- Won B.L., Hyung S.J, Yun M.Y., Seung B.J 2004 "Effect of PWHT on Behaviors of Precipitates and Hardness Distribution of 6061 Al Alloy Joints by Friction Stir Welding Method", Materials fourme (Volumes 449 - 452).

9- Paglia C.S. and Buchheit R.G., 2008 "A Look in the Corrosion of Aluminum Alloy Friction Stir Welds", Scripta Materialia, Vol.58, pp 383-387.

10- Fahimpour V., Sadrnezhaad S.K., Karimzadeh F., "Corrosion behavior of aluminum 6061 alloy joined by friction stir welding and gas tungsten arc welding methods ,2012", Materials \& Design Volume 39, February, pp. 329-333. 
11- Abbass M. K., Ameen H. A., and Hassan K. S., 2011 "Effect of heat treatment on corrosion resistance of friction stir welded AA 2024 aluminum alloy", American Journal of Scientific and Industrial Research, Vol. 2, No.2, pp.297- 306.

12-Feng J.C., Chen Y.C., and Liu H.J., 2006 "Effects of post-weld heat treatment on microstructure and mechanical properties of friction welded joints of 2219-O aluminum alloy", Materials Science and Technology, 22(1), pp.86-90.

13-Murr, LE; Liu, G; McClure, JC, 1997 "Dynamic recrystallization in the friction-stir welding of aluminium alloy 1100", Journal of Materials Science Letters 16 (22): pp. 801-1803.

14- David T. and James T., 1998 "Corrosion Science and Technology", CRC Press LLC,. Website at www.crepress.com.

15- Annual Book of ASTMSTANDARDS, 2004, Standard Practice for Calculation of Corrosion Rates and Related Information, G102-89, Vol. 03.02.

Table (1): Chemical composition analysis of $6061 \mathrm{~T} 6 \mathrm{Al}$ - alloy.

\begin{tabular}{|c|c|c|c|c|c|c|c|c|}
\hline Element & $\mathrm{Cu}$ & $\mathrm{Mn}$ & $\mathrm{Mg}$ & $\mathrm{Si}$ & $\mathrm{Fe}$ & $\mathrm{Cr}$ & $\mathrm{Zn}$ & $\mathrm{Al}$ \\
\hline Wt. \% & 0.23 & 0.13 & 0.3 & 0.64 & 0.42 & 0.17 & - & 98 \\
(Actual) & & & & & & & & \\
\hline Wt. \% & $0.15-$ & $\mathrm{Max}$ & $0.8-$ & $0.4-$ & $\mathrm{Max}$ & $0.04-$ & $\mathrm{Max}$ & Rem. \\
(Standard) & 0.4 & 0.15 & 1.2 & 0.8 & 0.7 & 0.35 & 0.25 & \\
\hline
\end{tabular}

Table (2): Specimen categorization.

\begin{tabular}{|c|c|}
\hline A & As weld without heat treatment \\
\hline B & Solution heat treatment at $500^{\circ} \mathrm{C}+$ artificial aging at $190^{\circ} \mathrm{C}$ for 2 hours \\
\hline C & Solution heat treatment at $500^{\circ} \mathrm{C}+$ artificial aging at $190^{\circ} \mathrm{C}$ for 4 hours \\
\hline D & Solution heat treatment at $500^{\circ} \mathrm{C}+$ artificial aging at $190^{\circ} \mathrm{C}$ for 6 hours \\
\hline
\end{tabular}

Table (3): Corrosion test result.

\begin{tabular}{|c|c|c|c|}
\hline Samples & $1 \mu A / \mathrm{Cm}^{2}$ & E mv & C.R (m.p y.) \\
\hline A & 223.22 & -732.2 & 98.21 \\
\hline B & 163.49 & -759.6 & 71.93 \\
\hline C & 177.21 & -710.3. & 77.97 \\
\hline D & 208.8 & -707.5 & 91.872 \\
\hline
\end{tabular}




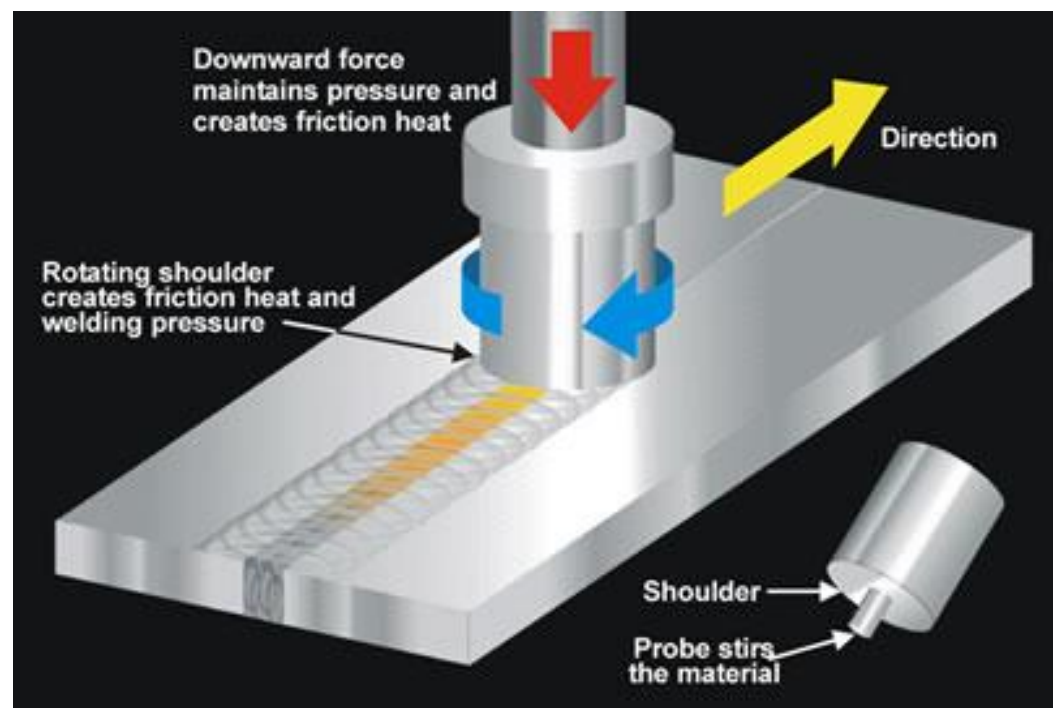

Fig. (1): Friction stir welding with a rotating tool.
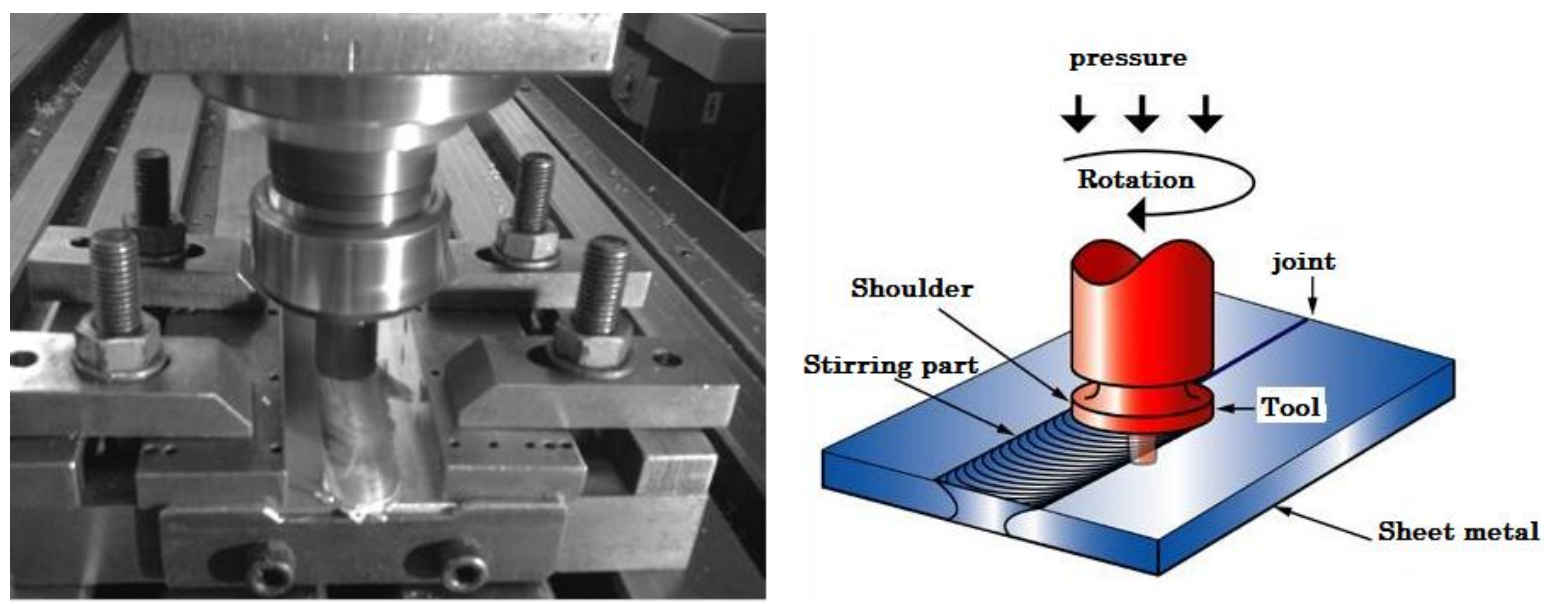

Fig. (2): Friction stirs welding process.
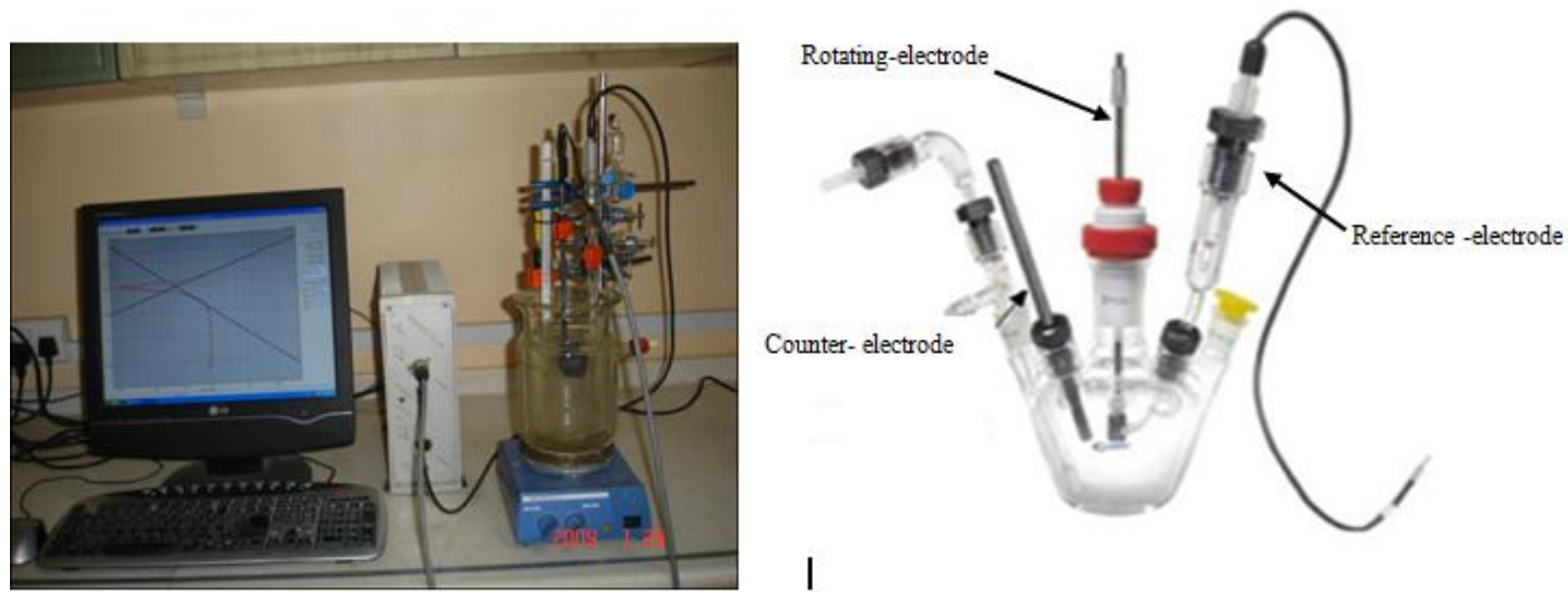

Fig. (3): The electrochemical corrosion unit and its cell. 


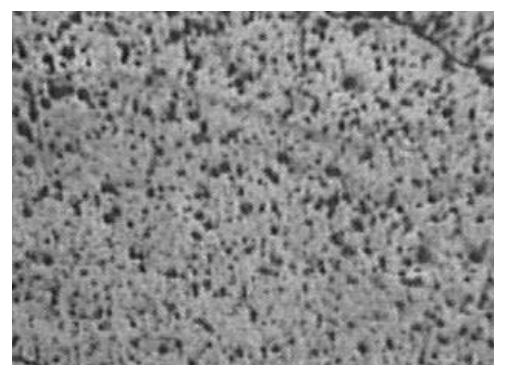

Base metal

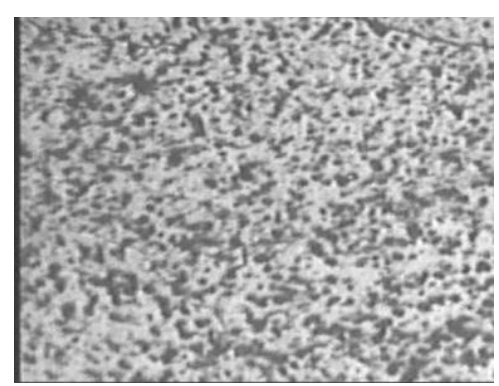

Weld zone

Fig. (4): Microstructure of the as-welded sample showing recrystallized grains with X $200 \mu \mathrm{m}$.

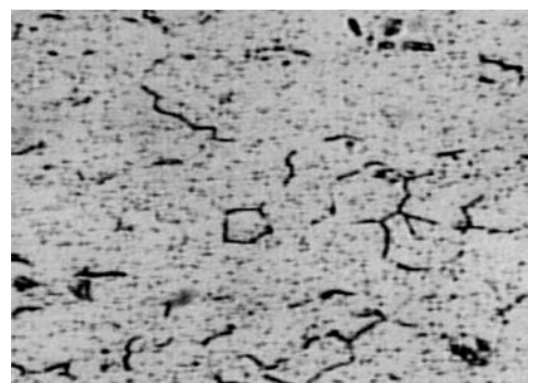

Sample A

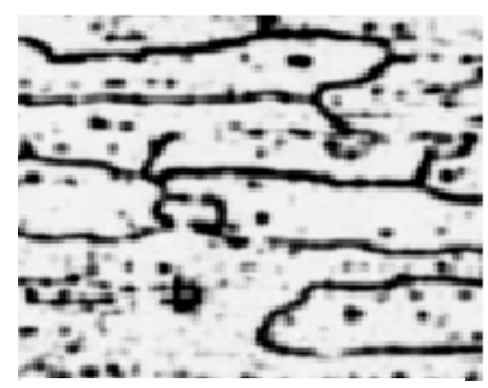

Sample A

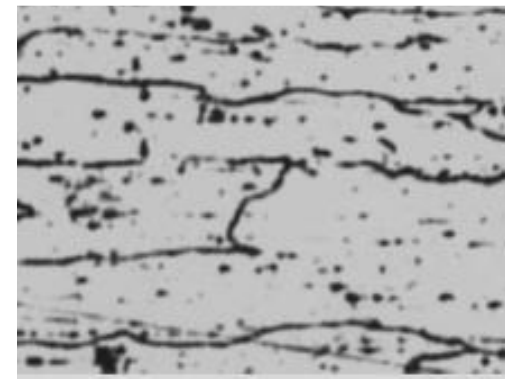

Sample B

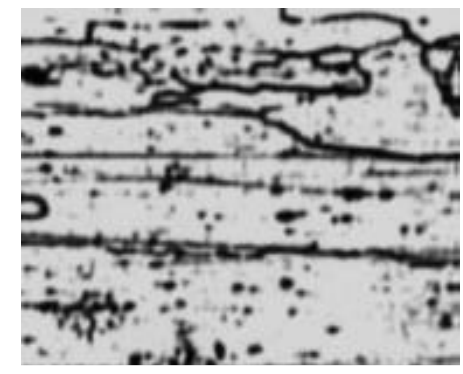

Sample B

Fig. (5): Microstructure with different ageing time with X $200 \mu \mathrm{m}$.

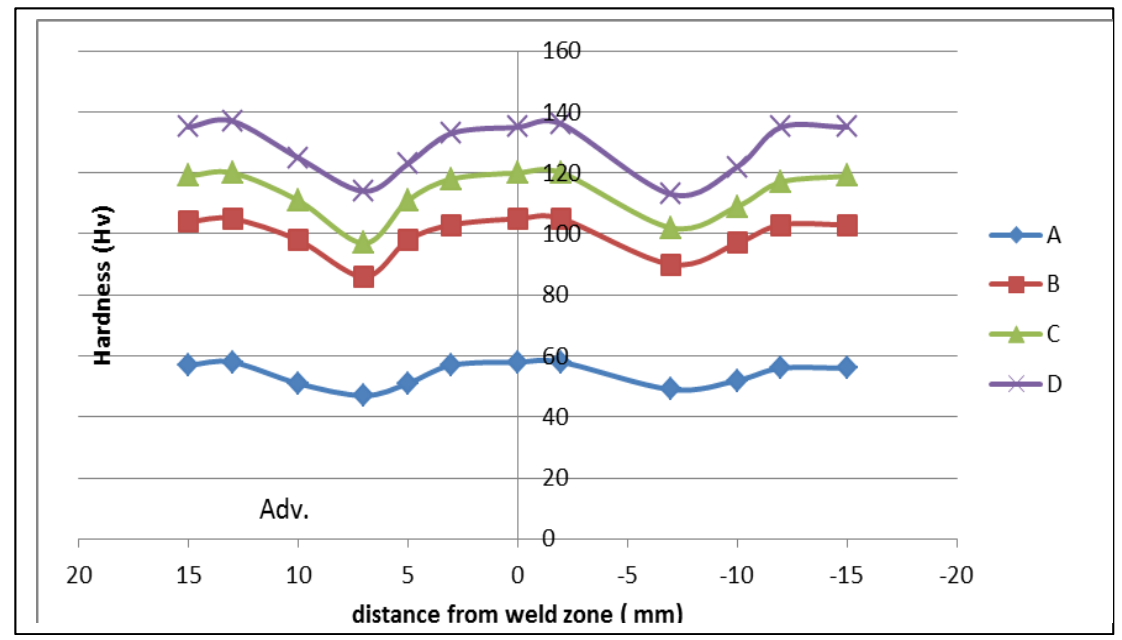

Fig. (6): Hardness profiles of a transverse cross section of welds for all specimens after age hardening heat treatment. 


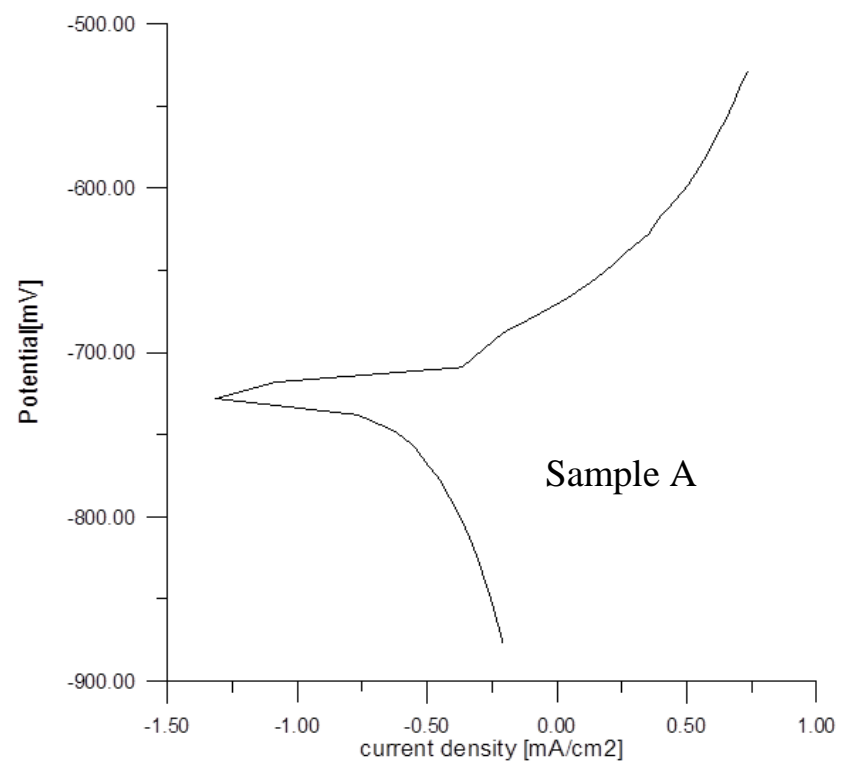

Fig. (7-a): Polarization curves for specimen (A).

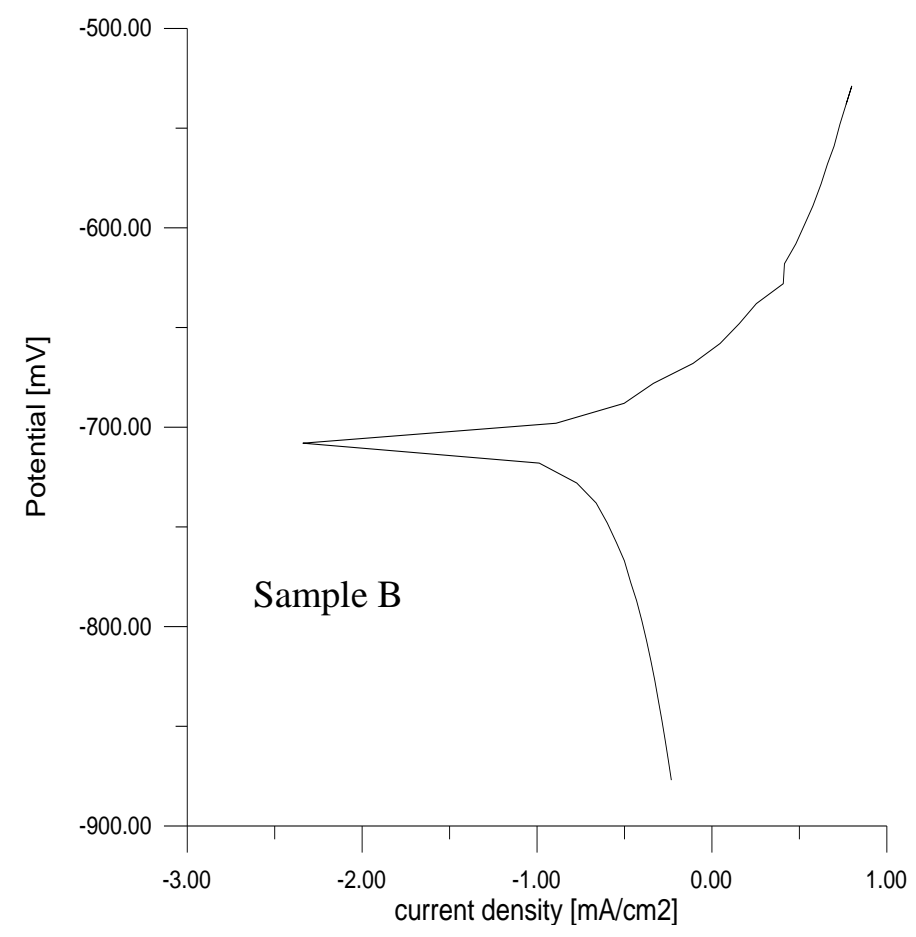

Fig. ( 7-b): Polarization curves for specimen (B). 


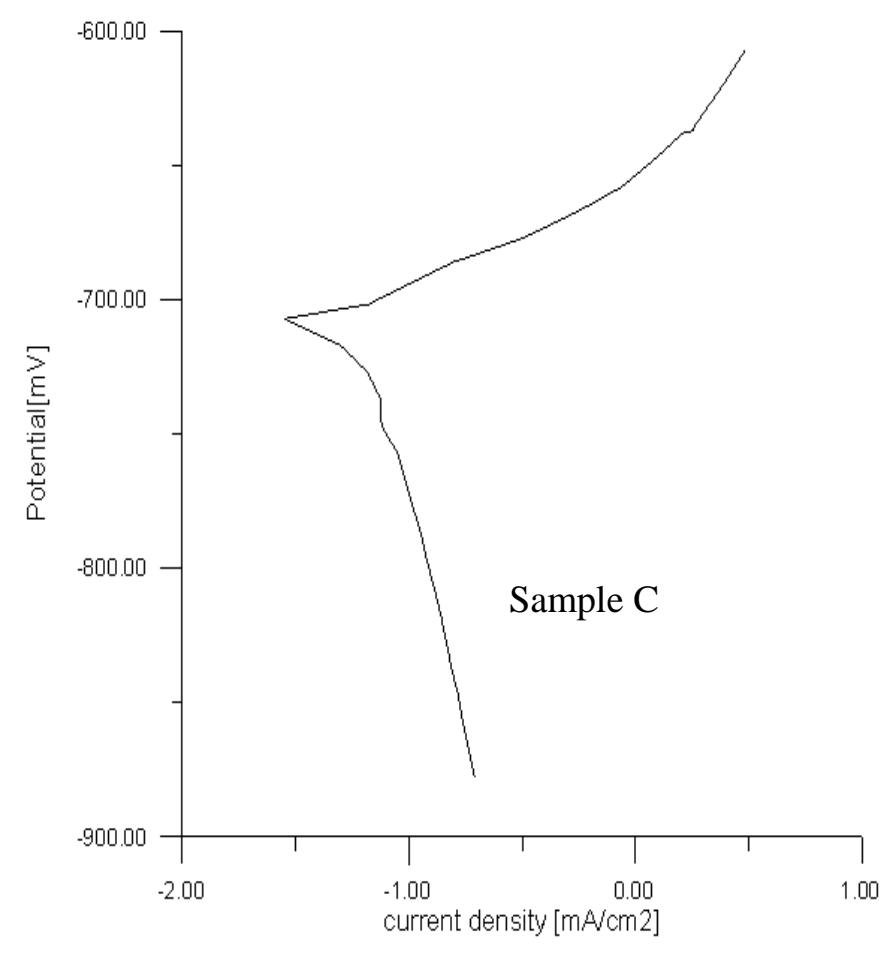

Fig. (7-c ): Polarization curves for specimen (C).

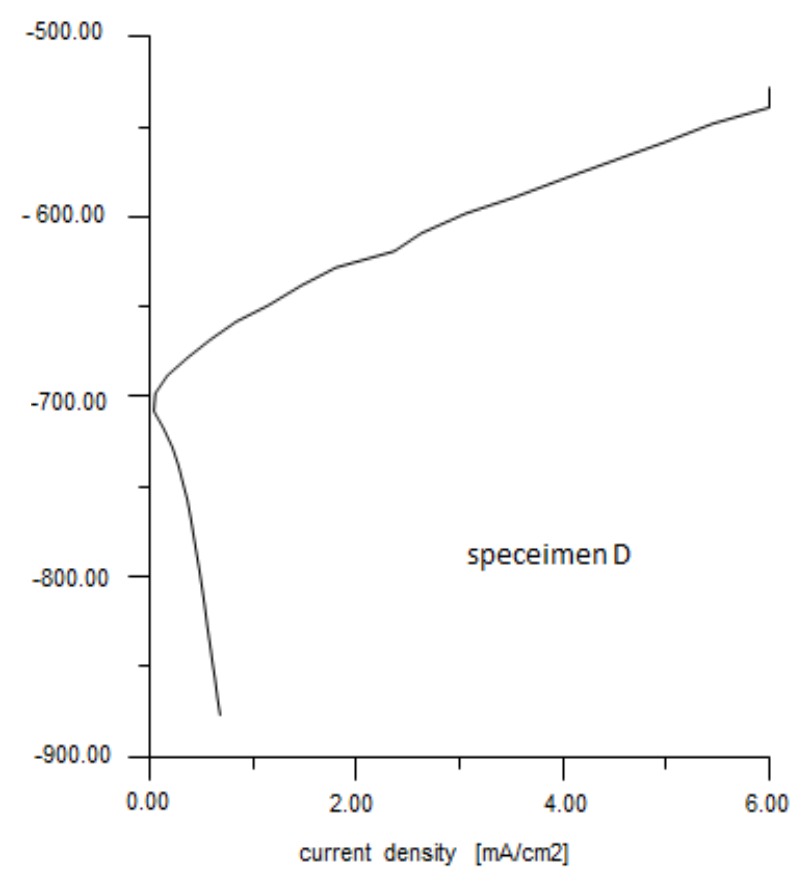

Fig. (7-d): Polarization curves for specimen (D). 


\section{تأثير زمن التعتيق الصناعي على مقاومة التآكل لوصلة لحام احتكاكي من الألمنيوم AA $6061 \mathrm{T6}$}

\author{
امجاد حسين عباس \\ مدرس مساعد \\ الجامعة التكنولوجية
}

\author{
نصير مالك عباس \\ مدرس مساعد \\ معهد التكنلوجيا/ بغداد
}

هدى محمد عبد العزيز مدرس مساعد التكنلوجيا/ بغداد

الخلاصة

يهدف البحث إلى دراسة تأثير المعاملات الحرارية على مقاومة التآكل لوصلات اللحام الاحتكاكي من سبيكة

ألمنيوم 6061T6 حيث نت فحص البنية المجهرية وسلوك التآكل للسبيكة قبل وبعد المعاملة الحرارية.

نم إجراء عملية لحام احتكاكي باستخدام ماكنة مبرمجة ذات قطب لحام دائري يدور بسرعة 1000 دورة

بالدقيقة و سرعة لحام 20 ملم/ دقيقة لإعداد وصلات لحام تتاكبية متعددة. ومن هذه الوصلات نم تصنيع عينات اختبار

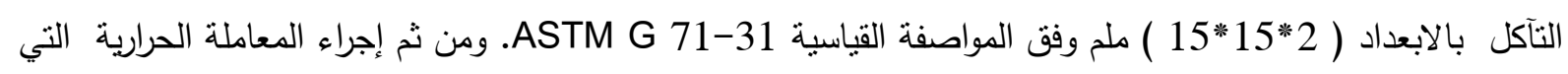

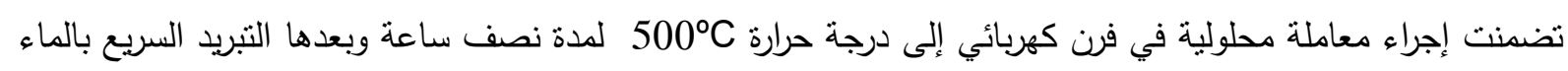
ثم نم إجراء تعتيق صناعي عن طريق إعادة التسخين إلى درجة 190C لفترات زمنيه 2,4,6 ساعة بعدهاء التبريد بالهواء.

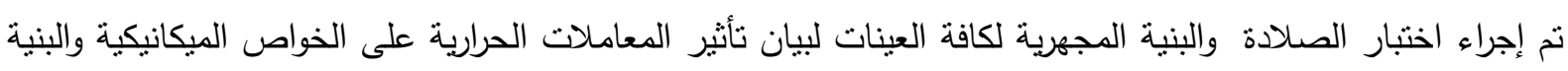
المجهرية للوصلات.

اجري اختبار تأكل كهروكيميائي قبل وبعد المعاملة الحرارية باستخدام جهاز المجهاد الساكن في وسط ماء البحر

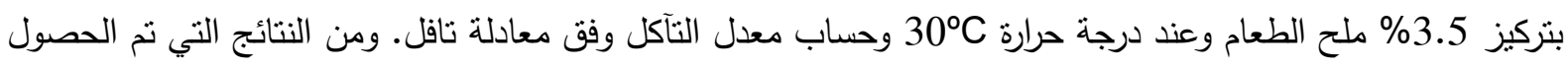
عليها وجد ان التعتيق الصناعي بعد عملية اللحام يحسن من مقاومة التآكل بسبب مساهمته بزيادة الأطوار المترسبة وان أفضل زمن تعنيق عند 2 مقارنة بزمن تعتيق عند 6,4 ساعة اي إن بزيادة زمن التعنيق يزداد معدل ترسيب العناصر المكونة للسبيكة. 